\title{
Optimizing Cutting Conditions for Minimum Surface Roughness in Face Milling of High Strength Steel Using Carbide Inserts
}

\author{
Adel Taha Abbas, ${ }^{1}$ Adham Ezzat Ragab, ${ }^{2}$ Essam Ali Al Bahkali, ${ }^{1}$ and Ehab Adel El Danaf ${ }^{1}$ \\ ${ }^{1}$ Department of Mechanical Engineering, College of Engineering, King Saud University, P.O. Box 800, Riyadh 11421, Saudi Arabia \\ ${ }^{2}$ Department of Industrial Engineering, College of Engineering, King Saud University, P.O. Box 800, Riyadh 11421, Saudi Arabia \\ Correspondence should be addressed to Adel Taha Abbas; atabbas1954@yahoo.com
}

Received 7 December 2015; Revised 3 March 2016; Accepted 6 March 2016

Academic Editor: Fernando Lusquiños

Copyright (c) 2016 Adel Taha Abbas et al. This is an open access article distributed under the Creative Commons Attribution License, which permits unrestricted use, distribution, and reproduction in any medium, provided the original work is properly cited.

\begin{abstract}
A full factorial design technique is used to investigate the effect of machining parameters, namely, spindle speed $(N)$, depth of cut $\left(a_{p}\right)$, and table feed rate $\left(V_{f}\right)$, on the obtained surface roughness $\left(R_{a}\right.$ and $\left.R_{t}\right)$ during face milling operation of high strength steel. A second-order regression model was built using least squares method depending on the factorial design results to approximate a mathematical relationship between the surface roughness and the studied process parameters. Analysis of variance was conducted to estimate the significance of each factor and interaction with respect to the surface roughness. For $R_{a}$, the results show that spindle speed, depth of cut, and table feed rate have a significant effect on the surface roughness in both linear and quadratic terms. There is also an interaction between depth of cut and feed rate. It also appears that feed rate has the greatest effect on the data variation followed by depth of cut. For $R_{t}$, the results show that the table feed rate is the most effective factor followed by the depth of cut, while the spindle speed had a significant small effect only in its quadratic term. The conditions of minimum $R_{a}$ and $R_{t}$ are identified through least square optimization. Moreover, multiobjective optimization for minimizing $R_{a}$ and maximizing metal removal rate $Q$ is conducted and the results are presented.
\end{abstract}

\section{Introduction}

Increasing product quality, delivery time, and productivity of the machined parts are the main challenges of metal-based industry. There has been increased interest in optimizing machining conditions to satisfy manufacturing requirements including the most prominent one, which is surface finish. Surface quality is considered as one of the most important criteria in manufacturing engineering. The performance and quality of a product are directly associated with surface integrity achieved by final machining, which is reflected in having small tolerance and minimum surface roughness, $R_{a}$. High productivity and throughput are directly correlated with high speed machining, which can be achieved by computer numerical controlled (CNC) milling technology. The automated and flexible manufacturing systems are employed for that purpose along with $\mathrm{CNC}$ machines that are capable of achieving high accuracy with very low processing time. Surface roughness is a key factor of surface quality, since it assumes an essential effect on wear resistance, ductility, tensile, and fatigue strength for machined parts.

Raju et al. [1] modeled and optimized the surface roughness in relation to the cutting parameters for 6061 aluminum alloy processed by end milling with high speed steel (HSS) and carbide tools under dry and wet conditions. A multiple regression analysis using analysis of variance was conducted and a second-order mathematical model of the cutting parameters was suggested. The predicted surface roughness $\left(R_{a}\right)$ from the model is compared to the values measured experimentally. It is reported, in this study, that feed rate is a dominant parameter and the surface roughness increases rapidly with increasing feed rate and decreases with increasing spindle speed, whereas the effect of depth of cut is not regular.

Pimenov [2] investigated the effect of feed, cutting speed, and tool wear of a T5K10 carbide tool on the roughness of flat surfaces, produced by face milling, of steel 45 . The 
TABLE 1: Chemical composition for high strength steel material.

\begin{tabular}{lcccccccccccc}
\hline $\mathrm{C}$ & $\mathrm{Si}$ & $\mathrm{Mn}$ & $\mathrm{Ni}$ & $\mathrm{Cr}$ & $\mathrm{Mo}$ & $\mathrm{V}$ & $\mathrm{S}$ & $\mathrm{Cu}$ & $\mathrm{P}$ & $\mathrm{Al}$ & $\mathrm{Fe}$ \\
\hline 0.356 & 0.221 & 0.728 & 2.697 & 1.030 & 0.617 & 0.103 & 0.005 & 0.176 & 0.010 & 0.006 & Balance \\
\hline
\end{tabular}

work analyzed the nature of the microprofile of changes in machined surfaces based on increasing the wear surface on the tooth flank. He showed that the roughness $R_{z}$ grew from 15 to $30 \%$ for the chosen cutting conditions with growth in the flank wear $\left(V_{b}\right)$ from 0 to $3.1-4 \mathrm{~mm}$. The increase in feed at a constant cutting speed led to an increase in the roughness; however, increasing cutting speed at constant feed led to a decrease in roughness. It was shown that, with an increase in the flank wear on the flank surface, the frequency of peaks and troughs of the profilograms of the microprofile of machined surface was decreased.

Pusavec et al. [3] studied alternative cooling/lubrication conditions compared to conventional machining of Inconel 718 and its relation to chip breakability. Genetic algorithms (GA) were used to evaluate and optimize the machining process in terms of tool-life, machined surface quality, chip breakability, productivity, and power consumption.

Felho and Kundrak [4] introduced a new method to calculate both the profile (2D) and surface (3D) parameters of theoretical roughness in the face milling of plain surfaces. This new method was based on an expediently developed CAD model and used a professional program for the roughness evaluation. Cutting experiments were performed on $42 \mathrm{CrMo} 4$ specimens in order to validate the accuracy of the model. The results have revealed that the method was able to predict surface roughness with good accuracy.

Rawangwong et al. [5] conducted a study on the surface roughness of a semisolid AA 7075 machined by face milling, using CNC milling machine with 63-millimeter diameter fine type carbide tool with twin cutting edge. The process factors were the speed, feed rate, and depth of cut. The results showed that the factor affecting surface roughness was the ratio of feed rate to the cutting speed while the depth of cut had no effect.

Kivak [6] used analysis of variance (ANOVA), Taguchi method, and regression analysis to investigate the effects of the machining parameters on surface roughness and flank wear for milling of Hadfield steel with PVD TiAlN- and CVD TiCN $/ \mathrm{Al}_{2} \mathrm{O}_{3}$-coated carbide inserts under dry milling conditions. Several experiments were conducted using full factorial design with a mixed orthogonal array on a $\mathrm{CNC}$ vertical machining center. The process variables were the cutting tool, cutting speed, and feed rate. It was concluded that the feed rate was the dominant factor affecting surface roughness, while cutting speed was the dominant factor affecting flank wear.

Rawangwong et al. [7] investigated the effect of main machining factors on the surface roughness of nodular cast iron FCD 400 face milled by carbide tools. The etching experiments were done using semiautomated milling machine Obraeci Strojie brand FGV 32 model. The factors studied were the speed, feed rate, and depth of cut. The experiments illustrated that the factors affecting surface roughness were feed rate and cutting speed with tendency for reduction of roughness values at lower feed rate and greater cutting speed.

Abbas [8] presented a performance comparative analysis, involving the criteria of surface roughness $\left(R_{a}, R_{t}\right.$, and $R_{z}$ ) during high strength steel's turning operation, between the conventional and wiper inserts. The main parameters considered in this study were the speed of cutting, the feed rate, and the depth of cut. The results showed the significance of cutting depth and feed rate in the reduction of surface roughness. It was reported that the quality of the surface derived with the wiper carbide insert had significant improvement in comparison to the conventional carbide insert. The maximum improvement of 3.5 times between the wiper insert and conventional insert was achieved at a cutting speed of $75 \mathrm{~m} / \mathrm{min}$.

The current work focuses on providing a comprehensive study on the effect of machining process parameters, namely, feed fate, cutting speed, and depth of cut, on the surface roughness, through a DOE full factorial design for face milling of high strength steel using carbide tools. Four levels for each process parameter are investigated. Analysis of variance (ANOVA) will be used to determine the effects of the machining parameters on surface roughness and to develop a mathematical model through regression analysis that best describes the variation within the experimental data.

\section{Materials and Methods}

This research study aims to investigate the effect of main factors on the surface roughness of high strength steel in face milling process using CNC milling machine and carbide inserts. Emco Mill Concept $45 \mathrm{CNC}$ vertical milling machine equipped with Sinumeric $840-\mathrm{D}$ with technical specifications including a speed range of 50-10,000 rpm and feed rate 0$10 \mathrm{~m} / \mathrm{min}$ was used. Workpiece samples are high strength steel with the chemical composition shown in Table 1. The heat treatment given to the material involved austenitizing at $900^{\circ} \mathrm{C}$ for $5 \mathrm{hr}$, followed by air cooling, heating at $880^{\circ} \mathrm{C}$ for $5 \mathrm{hr}$, quenching in oil, tempering at $590-600^{\circ} \mathrm{C}$ for $8 \mathrm{hr}$, and then air cooling. The resulting hardness achieved was HRC 41-43. The surface area of each sample is $40 \times 70 \mathrm{~mm}$ and height $60 \mathrm{~mm}$. The cutting tool with carbide inserts model face mill with tool holder Sandvik R245-063Q22-12M and Sandvik carbide coated inserts R245-12 T3M-PM4240 was used. The diameter of the cutter is $63 \mathrm{~mm}$ with 5 edges. This type of milling cutter was designed for high metal removal and mirror surface finish. It is designed with enhanced corners to reduce burr formation and frittering of 
TABLE 2: The cutting parameters and their levels used in the factorial design experiment.

\begin{tabular}{|c|c|c|c|c|c|}
\hline Designation & Process parameter & Level 1 & Level 2 & Level 3 & Level 4 \\
\hline$A$ & Spindle speed (rpm) & 500 & 750 & 1000 & 1250 \\
\hline$B$ & Depth of cut (mm) & 0.25 & 0.50 & 0.75 & 1.00 \\
\hline C & Feed rate $(\mathrm{mm} / \mathrm{min})$ & 50 & 75 & 100 & 125 \\
\hline
\end{tabular}

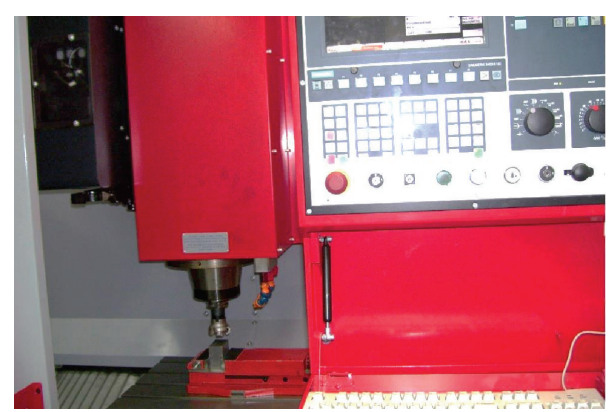

FIGURE 1: Test rig for machining the workpieces.

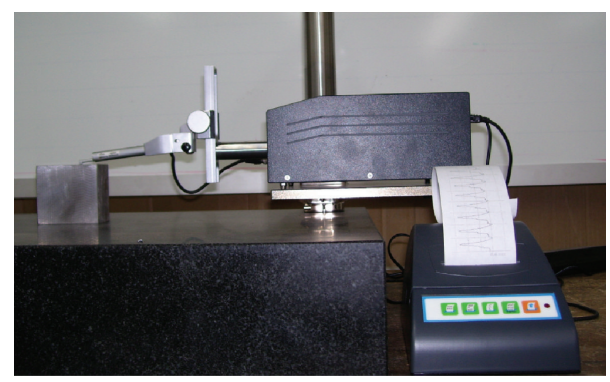

FIGURE 2: Test rig measuring the surface roughness.

the component. This type of cutter is suitable for face milling applications in all types of materials such as steel, stainless steel, cast iron, aluminum, and heat resistant and titanium alloys. The test rig for machining workpieces is shown in Figure 1. The surface roughness measuring device for evaluating the surface topography is model TESA Rugosurf 90-G and is shown in Figure 2.

The test plan was carried out through 64 test specimens, group (A), and repeated for producing replicates in group (B). Each group was divided into 16 groups. Every four groups are subjected to one common machining spindle speed. Groups $1-4,5-8,9-12$, and $13-16$ were processed using spindle speed machining of $500 \mathrm{rpm}, 750 \mathrm{rpm}, 1000 \mathrm{rpm}$, and $1250 \mathrm{rpm}$, respectively. Each group has been machined using four levels of cutting depth $(0.25,0.50,0.75$, and $1.0 \mathrm{~mm})$ and each depth was processed using four levels of table feed rates $(50,75$, 100 , and $125 \mathrm{~mm} / \mathrm{min})$. To apply the above conditions, CNC milling machine equipped with Sinumeric 840 -D was used. The surface roughness tester TESA was used to measure the surface roughness parameters, $R_{a}$ and $R_{t}$, where $R_{a}$ is arithmetic average deviation of the assessed profile and $R_{t}$ is maximum height of the profile. The machined surfaces were duplicated for each set of cutting conditions. Three readings of surface roughness were measured on each surface and the average was recorded in the Appendix for groups (A) and (B).

\section{Experimental Design}

Full factorial design is a comprehensive technique that requires a large number of experiments and yields a detailed description of all system relations and interactions. In this research, full factorial design was used to build the experiment with three independent variables (factors) and four levels for each. Table 2 summarizes the variables and their levels. Analysis of variance (ANOVA) was conducted to test the significance of the factors and their interaction with a confidence level of $95 \%$. Least squares method was used to build second-order multiple regression models. Minitab 17 was used to run the DOE analysis.

\section{Results and Discussion}

Figures 3(a) and 3(b) represent the effect of table feed rate on $R_{a}$ for different depth of cuts at spindle speed $500 \mathrm{rpm}$ in (a) and $1000 \mathrm{rpm}$ in (b). Preliminary observation of these curves indicates that the surface roughness values $\left(R_{a}\right)$ increase with increasing table feed rate for both rotational speeds. Comparing the effect of rotational speeds for two values of depth of cuts, of 1.0 and $0.25 \mathrm{~mm}$, can be seen in Figure 4 . For a depth of cut of $1.0 \mathrm{~mm}$, the value of surface roughness $\left(R_{a}\right)$ at spindle speed $1000 \mathrm{rpm}$ is higher compared to the $500 \mathrm{rpm}$. Opposing conclusion can be made for the $0.25 \mathrm{~mm}$ depth of cut, where the value of $R_{a}$ is higher at spindle speed $500 \mathrm{rpm}$ compared to the $1000 \mathrm{rpm}$. This draws towards the possibility of a saddle (minimax) point existing among the different machining conditions tested. This will be clearly verified in the surface plots presented in the next section. More detailed analysis will be conducted through analysis of variance in the following section.

4.1. ANOVA Results for $R_{a}$. Using Minitab 17 multiple regression option, the data were fit into a cubic model. However, the results showed a high level of multicollinearity between the cubic terms (third-order terms) and linear terms, even with coded data. To avoid this problem, the cubic terms were removed from the model. The adequacy of the model fit, measured by the coefficient of determination (adjusted $R$ squared), was reduced from $82 \%$ to $79 \%$ due to removing the cubic terms. 


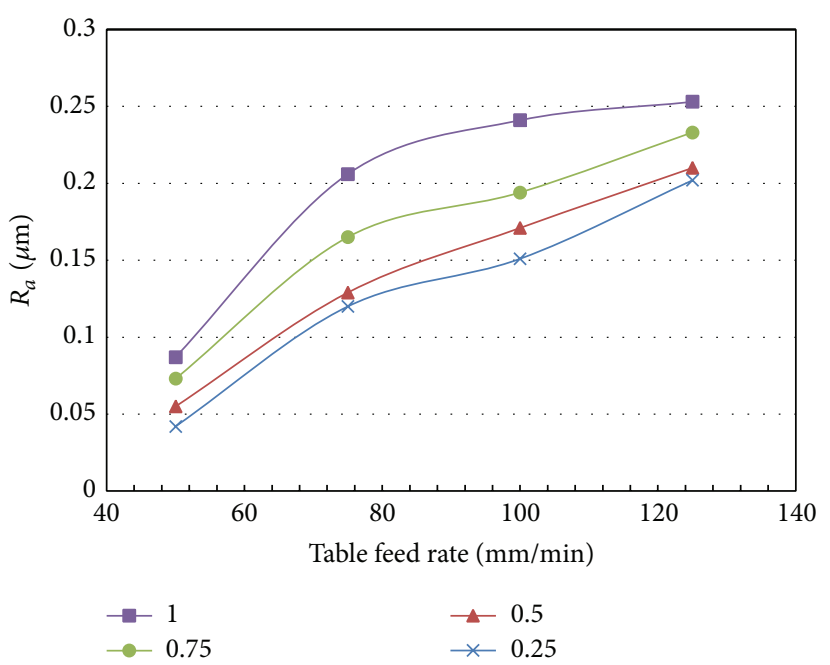

(a)

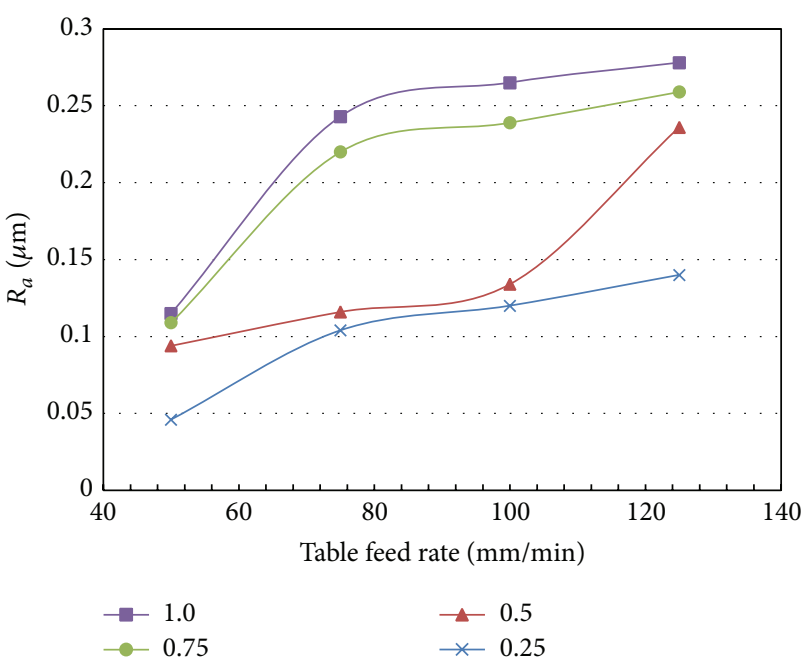

(b)

Figure 3: The effect of table feed rate on $R_{a}$ for different depth of cuts (mm) at $500 \mathrm{rpm}$ in (a) and $1000 \mathrm{rpm}$ in (b).

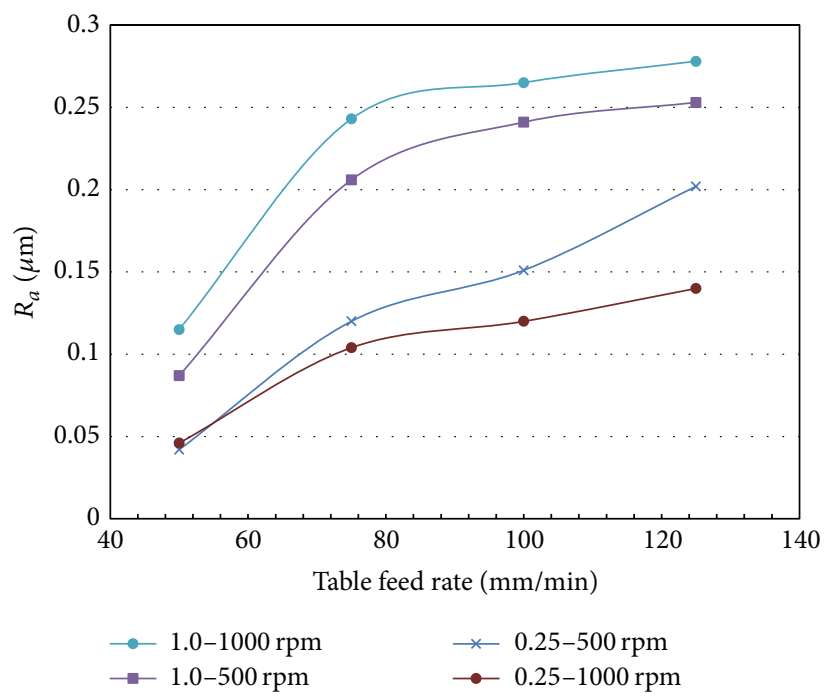

Figure 4: Effect of table feed rate on $R_{a}$ for two values of depth of cut, of 1.0 and $0.25 \mathrm{~mm}$, for two rotational spindle speeds of 500 and $1000 \mathrm{rpm}$.

ANOVA results of the model are presented in Table 3. $P$ values less than 0.05 indicate a significant term. Insignificant terms were then removed from the model one by one starting with terms that have the greatest $P$ value, unless it is a part of higher level term or interaction (Zhang and Chou [9], Fydrych and Rogalski [10], and Ding et al. [11]). The ANOVA results of the reduced model are given in Table 4. The percentage contribution column is calculated for each term as the percentage of the term's adjusted sum of squares to the total adjusted sum of squares. It provides a rough but effective estimation to the relative importance of each model term (Montgomery [12]).
The results show that spindle speed, depth of cut, and table feed rate have a significant effect on the surface roughness $\left(R_{a}\right)$ in both linear and quadratic terms. There is also an interaction between depth of cut and feed rate. However, looking at the percentage contribution column, it appears that factor $C$ (table feed rate) has the greatest effect on the data variation followed by factor $B$ (depth of cut).

Figure 5 shows the residual plots for the response $R_{a}$. Apparently, the residuals show no pattern and are distributed randomly against the fitted values and observation order. The normal probability plot and histogram show the normality of the residuals. The normality was tested using 
TABLE 3: ANOVA for $R_{a}$.

\begin{tabular}{|c|c|c|c|c|c|}
\hline Source & DF & Adj. SS & Adj. MS & $F$-value & $P$ value \\
\hline Regression & 10 & 0.476642 & 0.047664 & 47.92 & 0 \\
\hline$A$ & 1 & 0.005935 & 0.005935 & 5.97 & 0.016 \\
\hline$B$ & 1 & 0.102187 & 0.102187 & 102.74 & 0 \\
\hline$C$ & 1 & 0.317063 & 0.317063 & 318.79 & 0 \\
\hline$A * A$ & 1 & 0.01274 & 0.01274 & 12.81 & 0.001 \\
\hline$B * B$ & 1 & 0.017414 & 0.017414 & 17.51 & 0 \\
\hline$C * C$ & 1 & 0.011724 & 0.011724 & 11.79 & 0.001 \\
\hline$A * B$ & 1 & 0 & 0 & 0 & 0.999 \\
\hline$A * C$ & 1 & 0.002544 & 0.002544 & 2.56 & 0.112 \\
\hline$B * C$ & 1 & 0.00683 & 0.00683 & 6.87 & 0.01 \\
\hline$A * B * C$ & 1 & 0.000205 & 0.000205 & 0.21 & 0.65 \\
\hline Error & 117 & 0.116365 & 0.000995 & & \\
\hline Lack-of-fit & 53 & 0.116245 & 0.002193 & 1174.66 & 0 \\
\hline Pure error & 64 & 0.000119 & 0.000002 & & \\
\hline Total & 127 & 0.593006 & & & \\
\hline
\end{tabular}

TABLE 4: ANOVA for $R_{a}$ after removing insignificant terms.

\begin{tabular}{|c|c|c|c|c|c|c|}
\hline Source & $\mathrm{DF}$ & Adj. SS & Adj. MS & $F$-value & $P$ value & $\%$ contribution \\
\hline Regression & 7 & 0.473893 & 0.067699 & 68.2 & 0 & \\
\hline$A$ & 1 & 0.005935 & 0.005935 & 5.98 & 0.016 & 10.0 \\
\hline$B$ & 1 & 0.102187 & 0.102187 & 102.95 & 0 & 17.2 \\
\hline C & 1 & 0.317063 & 0.317063 & 319.42 & 0 & 53.5 \\
\hline$A * A$ & 1 & 0.01274 & 0.01274 & 12.83 & 0 & 2.1 \\
\hline$B * B$ & 1 & 0.017414 & 0.017414 & 17.54 & 0 & 2.9 \\
\hline$C * C$ & 1 & 0.011724 & 0.011724 & 11.81 & 0.001 & 2.0 \\
\hline$B * C$ & 1 & 0.00683 & 0.00683 & 6.88 & 0.01 & 1.2 \\
\hline Error & 120 & 0.119114 & 0.000993 & & & \\
\hline Lack-of-fit & 56 & 0.118994 & 0.002125 & 1138.02 & 0 & \\
\hline Pure error & 64 & 0.000119 & 0.000002 & & & \\
\hline Total & 127 & 0.593006 & & & & \\
\hline
\end{tabular}

Model summary

$R$-sq.: 79.91\%; $R$-sq. (adj.): 78.74\%; $R$-sq. (pred.): 77.39\%

Anderson-Darling normality test and the results proved that the residuals are normally distributed with $\mathrm{AD}$ value $=0.545$ and $P$ value $=0.158$ ( $P$ value $<0.05$ shows nonnormality $)$ as shown in Figure 6.

Model adequacy measures, reflected in the values of the coefficients of determination ( $R$-squared, adjusted $R$ squared, and predicted $R$-squared), show reasonable levels of model adequacy. With respect to adjusted $R$-squared, the model explains about $80 \%$ of the variation in the data. The value of $77 \%$ of the predicted $R$-squared is very close to the adjusted $R$-squared, which proves that the model is not overfit and has a good predictability.
Equation (1) is the regression equation for $R_{a}$ given by the reduced model. The optimum $R_{a}$ (minimum $R_{a}$ ) is given by the values $A=1250 \mathrm{rpm}, B=0.447 \mathrm{~mm}$, and $C=$ $50 \mathrm{~mm} / \mathrm{min}$. Figure 7 shows the optimization for $R_{a}$ :

$$
\begin{aligned}
R_{a}= & -0.1452+0.000255 A-0.2140 B+0.003876 C \\
& -0.000000 A^{2}+0.1866 B^{2}-0.000015 C^{2} \\
& +0.000935 B * C .
\end{aligned}
$$

Figures 8-10 show the surface plots of $R_{a}$ versus two of the processing parameters while fixing the third parameter at 

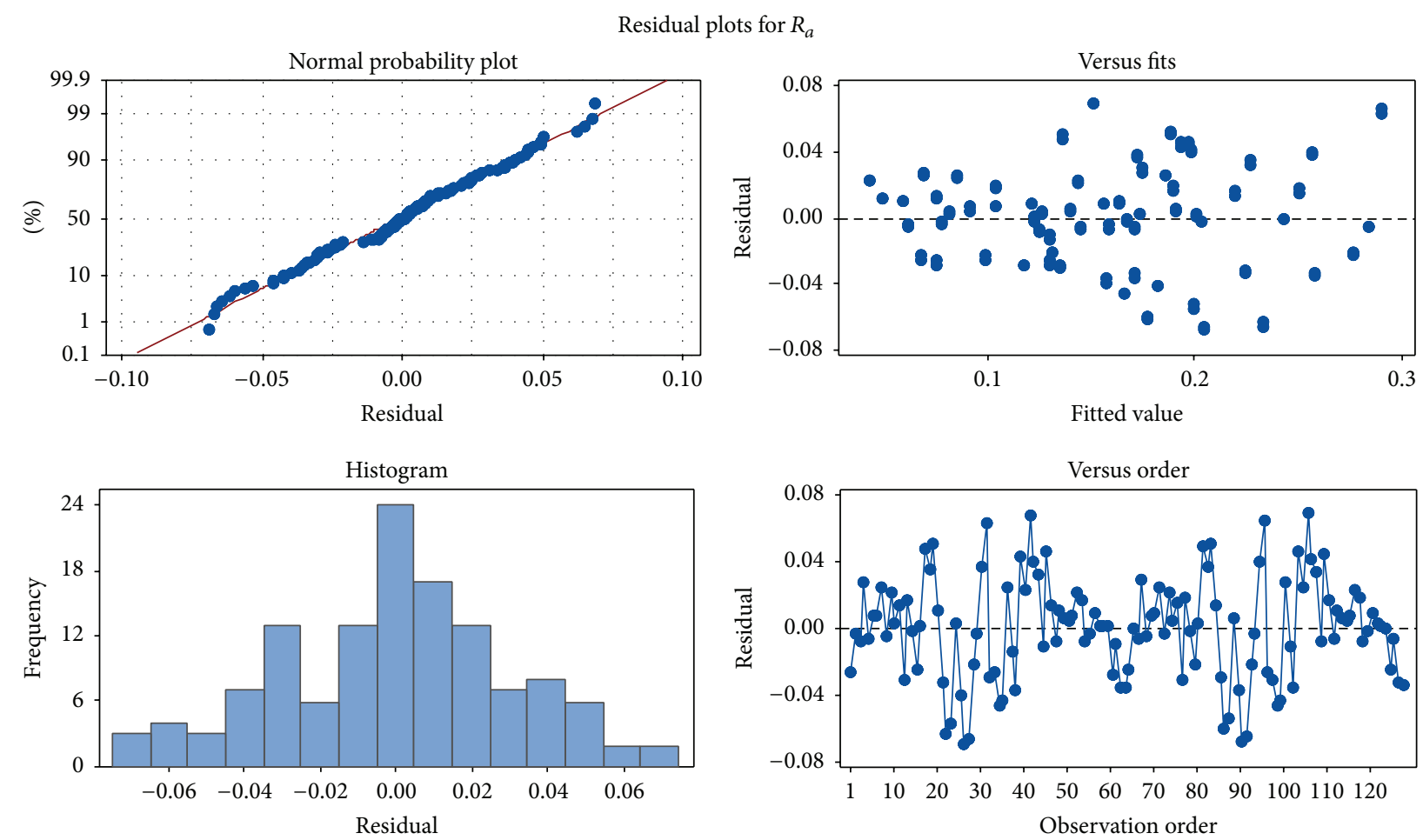

FIGURE 5: Residual plots for the response $R_{a}$.

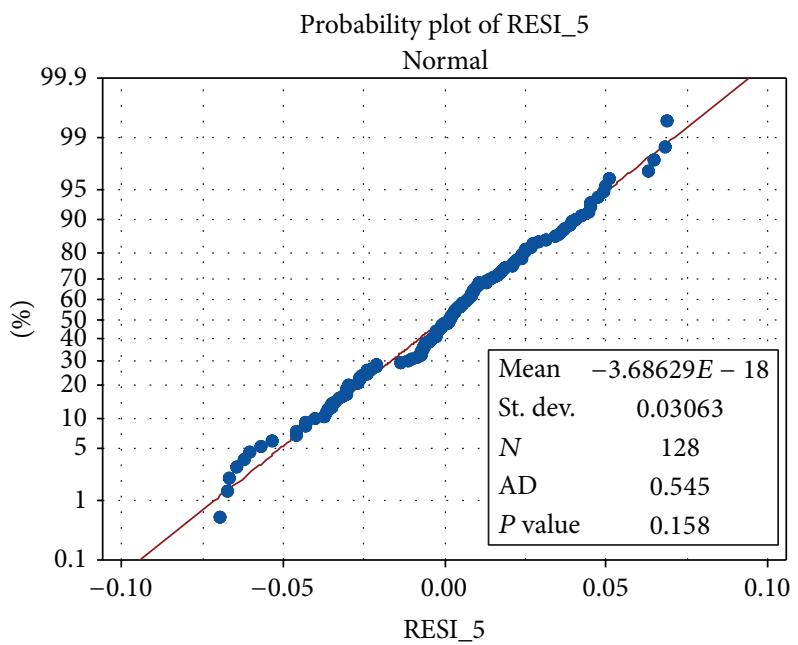

Figure 6: Anderson-Darling normality test results for $R_{a}$ residuals.

its mean value. The figures show the moderate curvature nature of the relationship between $R_{a}$ and the studied factors.

4.2. ANOVA Results for $R_{t}$. Running the analysis as described in Section 4.1, Table 5 shows the ANOVA final results of the model for $R_{t}$. However, the model could not be reduced due to the existence of significant third-level interaction ABC. The results show that the table feed rate is the most effective factor followed by the depth of cut on $R_{t}$, while the spindle speed had a significant small effect only in its quadratic term. Also, the interaction between the feed rate and depth of cut does exist as in the case of $R_{a}$.

Figure 11 shows the residual plots for the response $R_{a}$. Apparently, the residuals show no pattern and are distributed randomly against the fitted values and observation order. The normal probability plot and histogram show the normality of the residuals. The normality was tested using AndersonDarling normality test and the results proved that the residuals are normally distributed with $\mathrm{AD}$ value $=0.425$ and $P$ value $=0.311$ as shown in Figure 12 . 


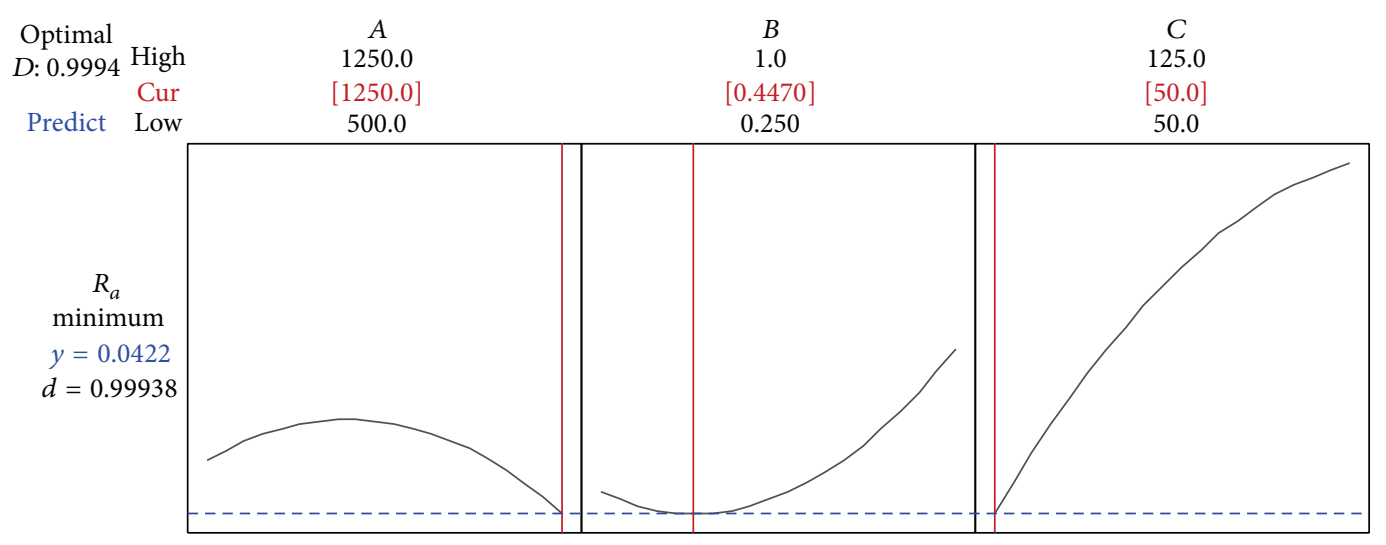

Figure 7: Optimization plot for $R_{a}$.

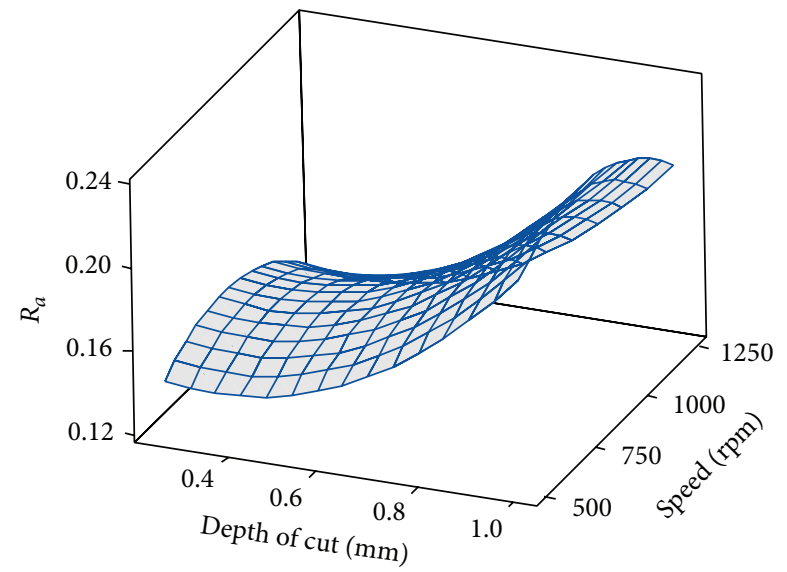

FIgURE 8: Surface plots for $R_{a}$ versus spindle speed and depth of cut at a mean table feed rate of $87.5 \mathrm{~mm} / \mathrm{min}$.

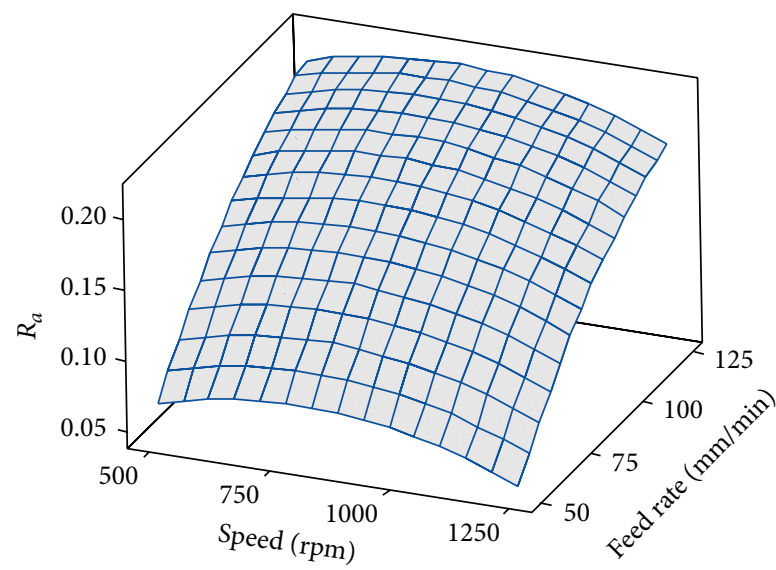

FIGURE 9: Surface plots for $R_{a}$ versus spindle speed and table feed rate at mean depth of cut of $0.625 \mathrm{~mm}$. 


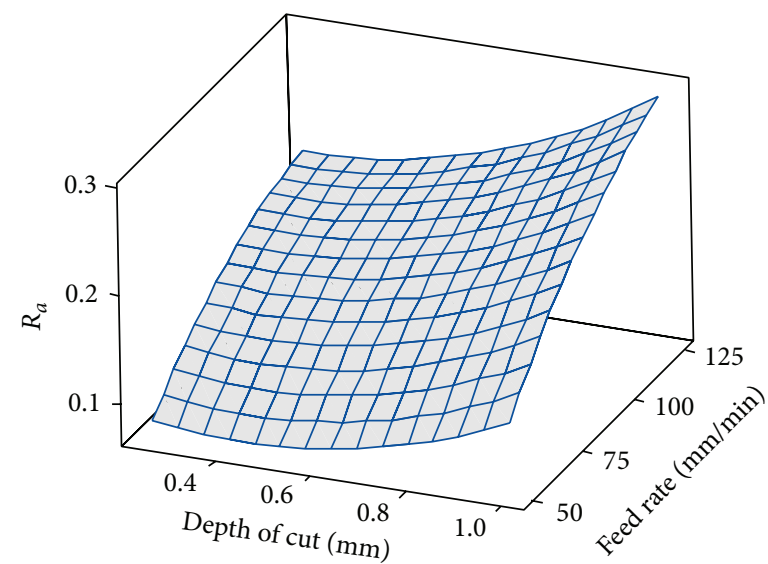

FIGURE 10: Surface plots for $R_{a}$ versus depth of cut and table feed rate at a mean spindle speed of $875 \mathrm{rpm}$.

TABLE 5: ANOVA for $R_{t}$.

\begin{tabular}{|c|c|c|c|c|c|c|}
\hline Source & DF & Adj. SS & Adj. MS & $F$-value & $P$ value & $\%$ contribution \\
\hline Regression & 10 & 23.6589 & 2.3659 & 56.45 & 0 & \\
\hline$A$ & 1 & 0.0003 & 0.0003 & 0.01 & 0.928 & 0.0 \\
\hline$B$ & 1 & 4.7025 & 4.7025 & 112.21 & 0 & 16.5 \\
\hline C & 1 & 14.9689 & 14.9689 & 357.19 & 0 & 52.4 \\
\hline$A * A$ & 1 & 0.9405 & 0.9405 & 22.44 & 0 & 3.3 \\
\hline$B * B$ & 1 & 0.8653 & 0.8653 & 20.65 & 0 & 3.0 \\
\hline$C * C$ & 1 & 1.0068 & 1.0068 & 24.02 & 0 & 3.5 \\
\hline$A * B$ & 1 & 0.0193 & 0.0193 & 0.46 & 0.499 & 0.1 \\
\hline$A * C$ & 1 & 0.1679 & 0.1679 & 4.01 & 0.048 & 0.6 \\
\hline$B * C$ & 1 & 0.2752 & 0.2752 & 6.57 & 0.012 & 1.0 \\
\hline$A * B * C$ & 1 & 0.7122 & 0.7122 & 16.99 & 0 & \\
\hline Error & 117 & 4.9032 & 0.0419 & & & \\
\hline Lack-of-fit & 53 & 4.9031 & 0.0925 & 37711.35 & 0 & \\
\hline Pure error & 64 & 0.0002 & 0 & & & \\
\hline Total & 127 & 28.5622 & & & & \\
\hline
\end{tabular}

Model summary

S: 0.204714 ; $R$-sq.: $82.83 \%$; $R$-sq. (adj.): $81.37 \%$; $R$-sq. (pred.): $79.01 \%$

The coefficients of determination values are comparable to that of $R_{a}$ and, hence, the same conclusions are valid. Equation (2) represents the relationship between $R_{t}$ and studied factors:

$$
\begin{aligned}
R_{t}= & -2.659+0.003758 A+1.000 B+0.04798 C \\
& -0.000001 A^{2}+1.316 B^{2}-0.000142 C^{2} \\
& -0.002832 A * B-0.000017 A * C-0.02395 B \\
& * C+0.000034 A * B * C .
\end{aligned}
$$

The values for optimum (minimum) $R_{t}$ are as follows: $A=$ $500 \mathrm{rpm}, B=0.29 \mathrm{~mm}$, and $C=50 \mathrm{~mm} / \mathrm{min}$. It is noticed that only the feed rate value is common between minimum $R_{a}$ and minimum $R_{t}$.
4.3. Multiobjective Optimization for $R_{a}$ and Metal Removal Rate (Q). Though reducing the feed rate and depth of cut improves the surface roughness, it also reduces the metal removal rate $(Q)$ which is a measure of productivity during the machining process. Maximizing $(Q)$ should be a goal from the economic point of view. In this analysis, multiobjective optimization was conducted to minimize $R_{a}$ and maximize $(Q)$ simultaneously. Metal removal rate was calculated according to

$$
Q=a_{p} * a_{e} * V_{f},
$$

where $a_{e}$ is working engagement being $35 \mathrm{~mm}$ in all test experiments.

A target was set to minimize $R_{a}$ and to maximize (Q) keeping $R_{a}$ between 0.15 and $0.2 \mu \mathrm{m}$ (from industrial 

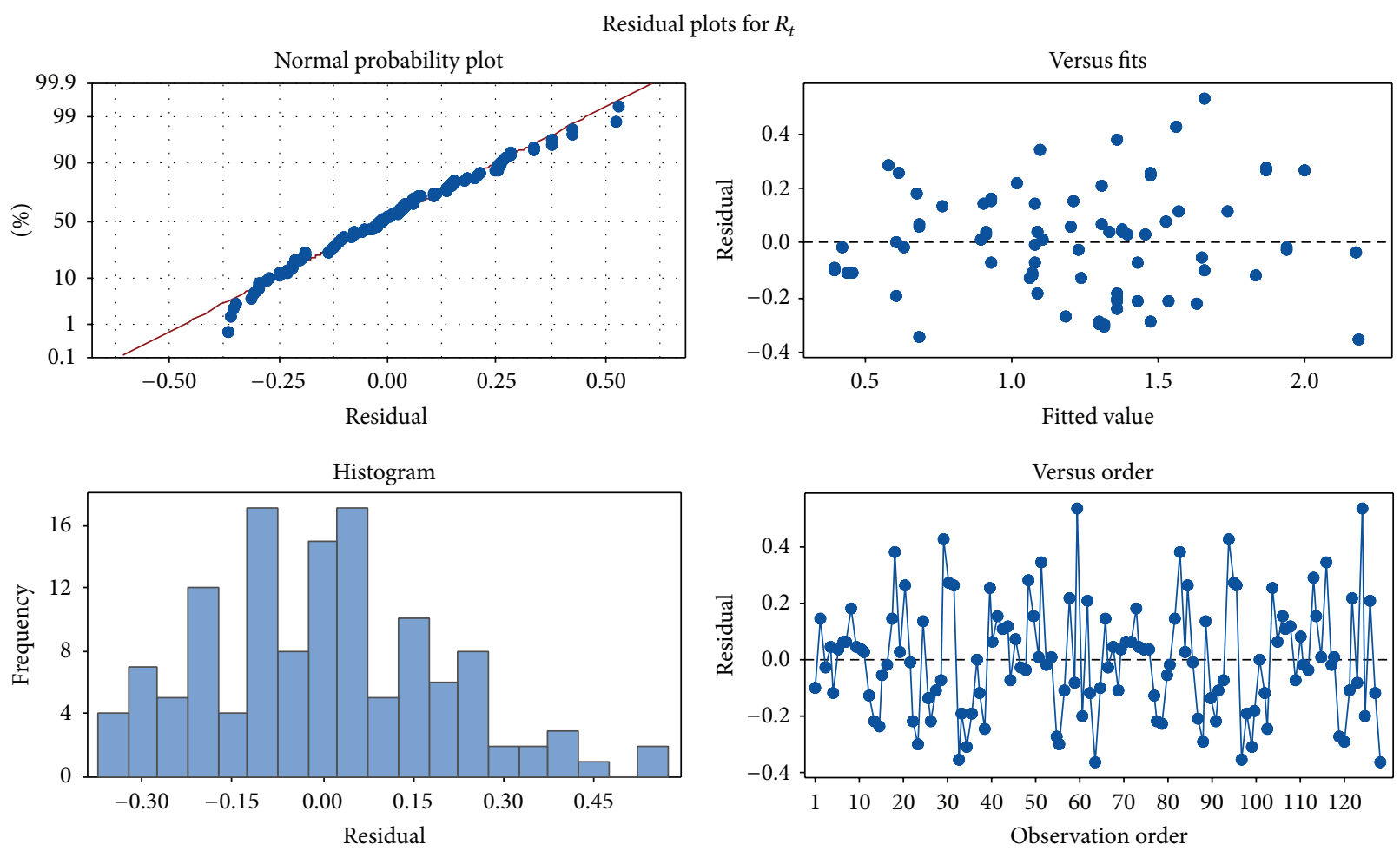

FIGURE 11: Residual plots for the response $R_{t}$.

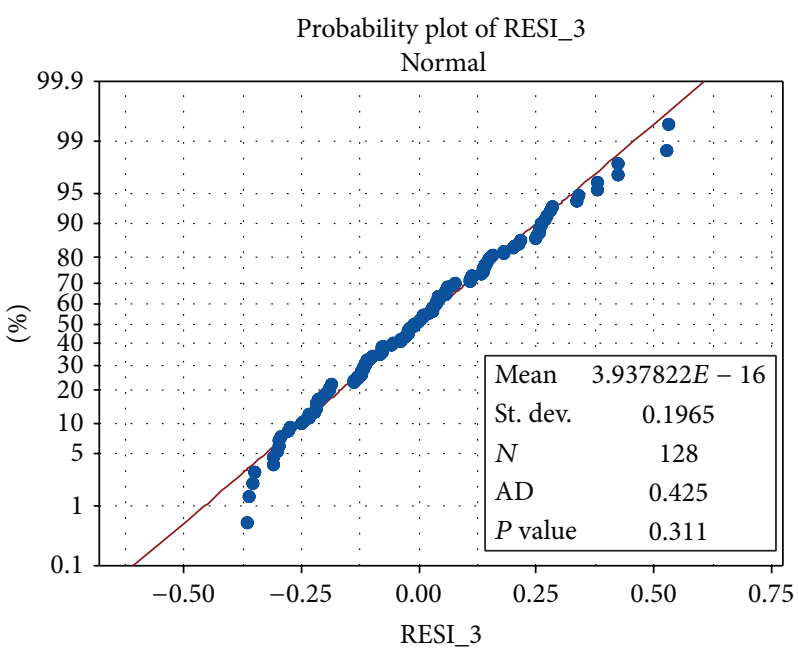

FIgURE 12: Anderson-Darling normality test results for $R_{a}$ residuals.

experience for fine milling) with higher priority to optimizing (Q). The optimization resulted in spindle speed $=1250 \mathrm{rpm}$, depth of cut $=1.0 \mathrm{~mm}$, and table feed rate $=67 \mathrm{~mm} / \mathrm{min}$ with composite desirability of 0.83 . Composite desirability measures the goodness of optimization and ranges between zero and one, where one is the ideal case and zero means that at least one of the terms is out of limits. The expected $R_{a}$ and (Q) were calculated to be $0.15 \mu \mathrm{m}$ and $2333 \mathrm{~mm}^{3} / \mathrm{min}$, respectively. Figure 13 shows the multiobjective optimization plot.
High strength steel has relatively high hardness that correlates well with good surface quality. This is due to the harder material possessing low plastic flow capability which results in better surface finish. This is attributed to the brittle nature of the interaction between the cutting tool and the workpiece surface, for the hard materials, that leads to material separation rather than plastic flow that would result in surface irregularities. Surface roughness was found to increase with increasing feed rate and depth of cut which both result in bigger cut areas that are consequently 


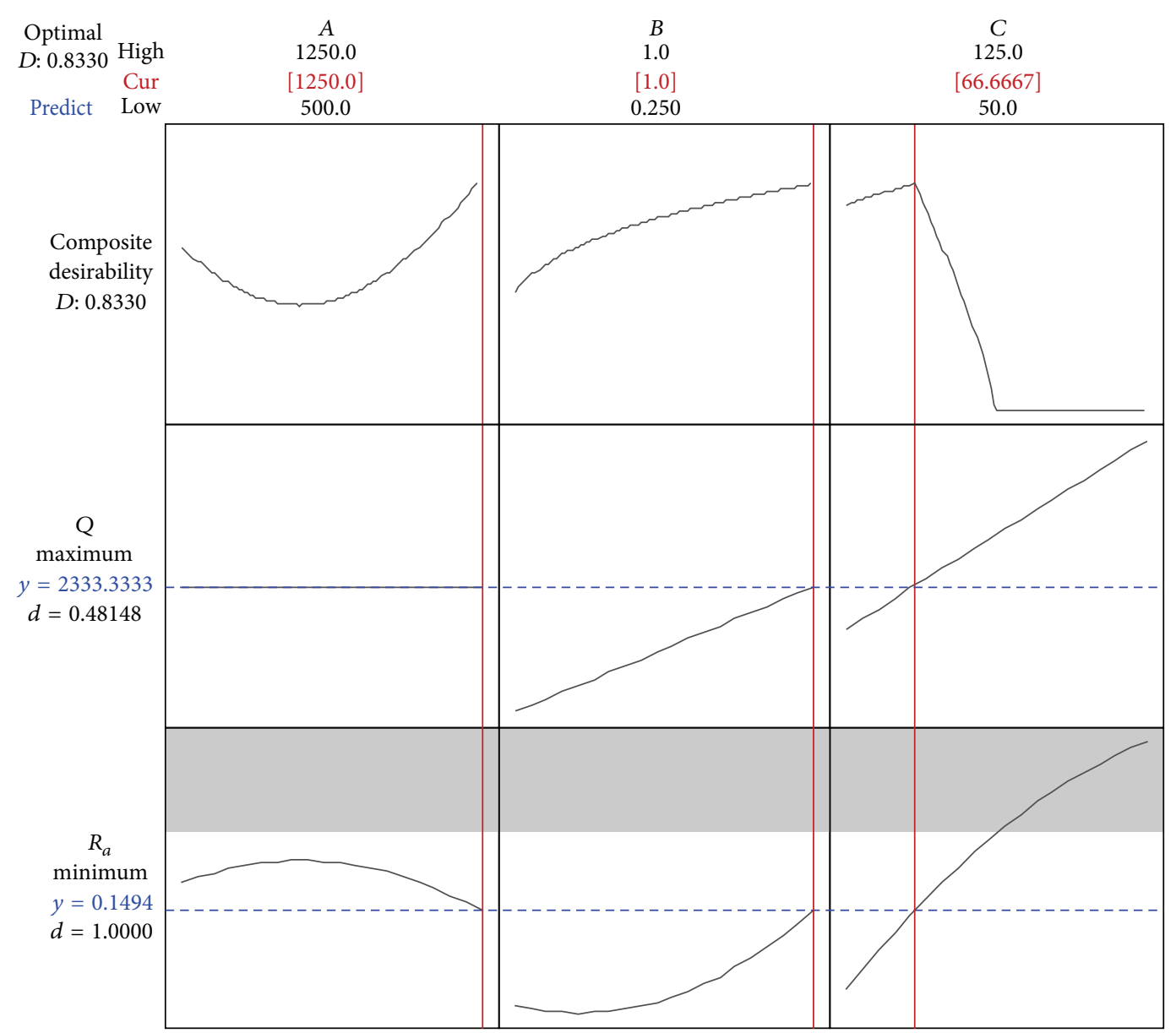

FIgURE 13: Multiobjective optimization plot for $R_{a}$ and metal removal rate (Q).

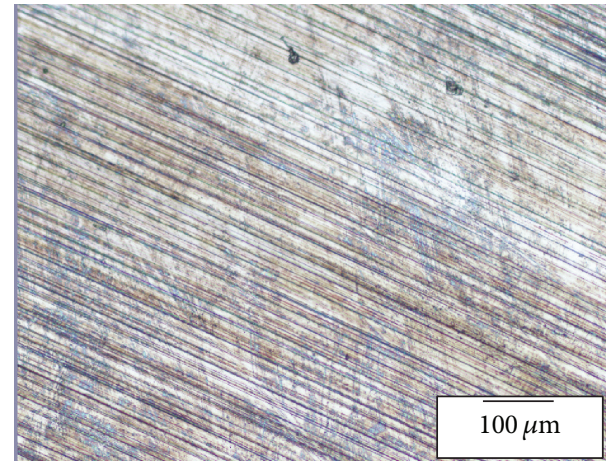

Figure 14: Optical microscopy of the machined surface under spindle speed $=1250 \mathrm{rpm}$, depth of cut $=0.5 \mathrm{~mm}$, and table feed rate $=50 \mathrm{~mm} / \mathrm{min}$.

associated with higher cutting forces and higher friction which lead to poor surface finish. It was noticed from the surface roughness profile that high feed rates were associated with larger roughness markings horizontal spacing. Also, with higher depth of cuts, the vertical spacing between peaks and troughs of the surface irregularities was larger. Thus,

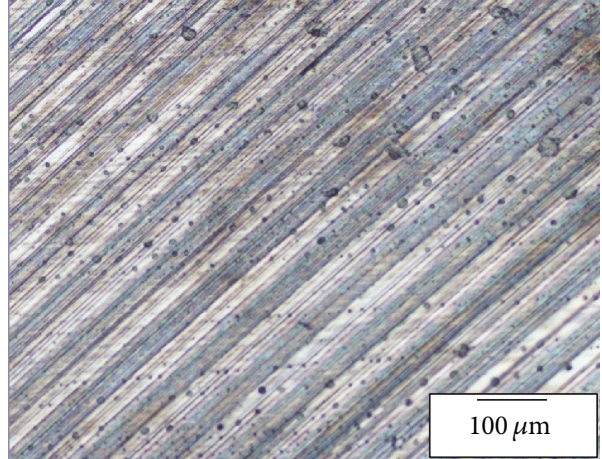

FIGURE 15: Optical microscopy of the machined surface under spindle speed $=1250 \mathrm{rpm}$, depth of cut $=0.5 \mathrm{~mm}$, and table feed rate $=125 \mathrm{~mm} / \mathrm{min}$.

higher feed rates and depth of cuts led to higher surface roughness.

Figure 14 represents an optical microscopy of the machined surface under spindle speed of $1250 \mathrm{rpm}$, depth of cut of $0.5 \mathrm{~mm}$, and table feed rate of $50 \mathrm{~mm} / \mathrm{min}$, while Figure 15 represents an optical microscopy for the following 
TABLE 6: Cutting conditions for group A.

\begin{tabular}{|c|c|c|c|c|c|c|}
\hline \multirow{2}{*}{$\begin{array}{l}\text { Test } \\
\text { number }\end{array}$} & \multirow{2}{*}{$\begin{array}{c}\text { Group } \\
\#\end{array}$} & \multirow{2}{*}{$\begin{array}{c}\text { Spindle speed } \\
(\mathrm{rpm})\end{array}$} & \multirow{2}{*}{$\begin{array}{c}\text { Depth of cut } \\
(\mathrm{mm})\end{array}$} & \multirow{2}{*}{$\begin{array}{l}\text { Table feed } \\
(\mathrm{mm} / \mathrm{min})\end{array}$} & \multicolumn{2}{|c|}{ Surface finish $(\mu \mathrm{m})$} \\
\hline & & & & & $R_{a}$ & $R_{t}$ \\
\hline $\mathrm{A} 1$ & \multirow{4}{*}{$\mathrm{A} 1$} & \multirow{4}{*}{500} & \multirow{4}{*}{0.25} & 50 & 0.042 & 0.295 \\
\hline A2 & & & & 75 & 0.120 & 1.039 \\
\hline A3 & & & & 100 & 0.151 & 1.198 \\
\hline A4 & & & & 125 & 0.202 & 1.419 \\
\hline A5 & \multirow{4}{*}{$\mathrm{A} 2$} & \multirow{4}{*}{500} & \multirow{4}{*}{0.5} & 50 & 0.055 & 0.336 \\
\hline A6 & & & & 75 & 0.129 & 0.945 \\
\hline A7 & & & & 100 & 0.171 & 1.256 \\
\hline A8 & & & & 125 & 0.210 & 1.366 \\
\hline A9 & \multirow{4}{*}{ A3 } & \multirow{4}{*}{500} & \multirow{4}{*}{0.75} & 50 & 0.073 & 0.855 \\
\hline A10 & & & & 75 & 0.165 & 1.132 \\
\hline A11 & & & & 100 & 0.194 & 1.369 \\
\hline A12 & & & & 125 & 0.233 & 1.426 \\
\hline A13 & \multirow{4}{*}{ A4 } & \multirow{4}{*}{500} & \multirow{4}{*}{1.00} & 50 & 0.087 & 0.928 \\
\hline A14 & & & & 75 & 0.206 & 1.216 \\
\hline A15 & & & & 100 & 0.241 & 1.400 \\
\hline A16 & & & & 125 & 0.253 & 1.596 \\
\hline A17 & \multirow{4}{*}{ A5 } & \multirow{4}{*}{750} & \multirow{4}{*}{0.25} & 50 & 0.083 & 0.607 \\
\hline A18 & & & & 75 & 0.184 & 1.220 \\
\hline A19 & & & & 100 & 0.208 & 1.736 \\
\hline A20 & & & & 125 & 0.239 & 1.478 \\
\hline A21 & & & & 50 & 0.085 & 0.871 \\
\hline A22 & A6 & 750 & 0.5 & 75 & 0.104 & 1.069 \\
\hline A23 & & & & 100 & 0.115 & 1.149 \\
\hline A24 & & & & 125 & 0.143 & 1.177 \\
\hline A25 & & & & 50 & 0.094 & 0.901 \\
\hline A26 & A7 & 750 & 0.75 & 75 & 0.118 & 1.103 \\
\hline A27 & N & 130 & 0.73 & 100 & 0.136 & 1.316 \\
\hline A28 & & & & 125 & 0.167 & 1.547 \\
\hline A29 & & & & 50 & 0.109 & 1.002 \\
\hline A30 & A8 & 750 & & 75 & 0.201 & 1.991 \\
\hline A31 & & 100 & 1.00 & 100 & 0.294 & 2.140 \\
\hline A 32 & & & & 125 & 0.354 & 2.263 \\
\hline A33 & & & & 50 & 0.046 & 0.334 \\
\hline A34 & A9 & 1000 & 0.25 & 75 & 0.104 & 0.899 \\
\hline A35 & A9 & 1000 & 0.25 & 100 & 0.120 & 1.005 \\
\hline A36 & & & & 125 & 0.140 & 1.174 \\
\hline A37 & & & & 50 & 0.094 & 0.601 \\
\hline A38 & A10 & 1000 & 0.5 & 75 & 0.116 & 0.950 \\
\hline A39 & RIV & 1000 & 0.5 & 100 & 0.134 & 1.109 \\
\hline $\mathrm{A} 40$ & & & & 125 & 0.236 & 1.719 \\
\hline A41 & & & & 50 & 0.109 & 0.743 \\
\hline $\mathrm{A} 42$ & A11 & 1000 & 0.75 & 75 & 0.220 & 1.364 \\
\hline A43 & & & & 100 & 0.239 & 1.675 \\
\hline A44 & & & & 125 & 0.259 & 1.855 \\
\hline A45 & & & & 50 & 0.115 & 0.853 \\
\hline A46 & $\mathrm{A} 12$ & 1000 & 1.00 & 75 & 0.243 & 1.598 \\
\hline A47 & & & & 100 & 0.265 & 1.914 \\
\hline $\mathrm{A} 48$ & & & & 125 & 0.278 & 2.140 \\
\hline
\end{tabular}


TABLE 6: Continued.

\begin{tabular}{|c|c|c|c|c|c|c|}
\hline \multirow{2}{*}{$\begin{array}{l}\text { Test } \\
\text { number }\end{array}$} & \multirow{2}{*}{$\begin{array}{c}\text { Group } \\
\# \\
\end{array}$} & \multirow{2}{*}{$\begin{array}{c}\text { Spindle speed } \\
(\mathrm{rpm})\end{array}$} & \multirow{2}{*}{$\begin{array}{c}\text { Depth of cut } \\
(\mathrm{mm})\end{array}$} & \multirow{2}{*}{$\begin{array}{l}\text { Table feed } \\
(\mathrm{mm} / \mathrm{min})\end{array}$} & \multicolumn{2}{|c|}{ Surface finish $(\mu \mathrm{m})$} \\
\hline & & & & & $R_{a}$ & $R_{t}$ \\
\hline A 49 & \multirow{4}{*}{$\mathrm{A} 13$} & \multirow{4}{*}{1250} & \multirow{4}{*}{0.25} & 50 & 0.060 & 0.859 \\
\hline A50 & & & & 75 & 0.110 & 1.082 \\
\hline A51 & & & & 100 & 0.144 & 1.112 \\
\hline A52 & & & & 125 & 0.165 & 1.435 \\
\hline A53 & \multirow{4}{*}{$\mathrm{A} 14$} & \multirow{4}{*}{1250} & \multirow{4}{*}{0.5} & 50 & 0.064 & 0.404 \\
\hline A54 & & & & 75 & 0.121 & 0.896 \\
\hline A55 & & & & 100 & 0.137 & 0.907 \\
\hline A56 & & & & 125 & 0.165 & 0.996 \\
\hline A57 & \multirow{4}{*}{$\mathrm{A} 15$} & \multirow{4}{*}{1250} & \multirow{4}{*}{0.75} & 50 & 0.068 & 0.321 \\
\hline A58 & & & & 75 & 0.128 & 1.233 \\
\hline A59 & & & & 100 & 0.174 & 1.348 \\
\hline A60 & & & & 125 & 0.203 & 2.186 \\
\hline A61 & \multirow{4}{*}{ A16 } & \multirow{4}{*}{1250} & \multirow{4}{*}{1.00} & 50 & 0.072 & 0.409 \\
\hline A62 & & & & 75 & 0.163 & 1.514 \\
\hline A63 & & & & 100 & 0.190 & 1.713 \\
\hline A64 & & & & 125 & 0.223 & 1.820 \\
\hline
\end{tabular}

cutting conditions: spindle speed of $1250 \mathrm{rpm}$, depth of cut of $0.5 \mathrm{~mm}$, and table feed rate of $125 \mathrm{~mm} / \mathrm{min}$. The effect of feed rate is obvious, in a sense that low feed rate produced relatively thin surface roughness markings that are closely spaced, whereas high feed rate produced relatively thick roughness markings that are distantly spaced.

\section{Conclusion}

ANOVA and regression analysis, through a DOE full factorial design $\left(4^{3}\right)$, were conducted to relate the surface roughness of face milled high strength steel to the most common machining parameters, namely, table feed rate, depth of cut, and spindle speed. Two surface roughness indicators, namely, $R_{a}$ and $R_{t}$, were experimentally measured through a set of 64 experiments and their replicates. The recorded roughness values are the average of four readings on each surface. For $R_{a}$, the results show that speed, depth of cut, and table feed rate have a significant effect on the surface roughness in both linear and quadratic terms. There is also an interaction between depth of cut and feed rate. It also appears that feed rate has the greatest effect on the data variation followed by depth of cut. The minimum $R_{a}$ was achieved at the following machining conditions: spindle speed $=1250 \mathrm{rpm}$, depth of cut $=0.447 \mathrm{~mm}$, and table feed rate $=50 \mathrm{~mm} / \mathrm{min}$. For $R_{t}$, the results show that the feed rate is the most effective factor followed by the depth of cut, while the speed had a significant small effect only in its quadratic term. Also, the interaction between the feed rate and depth of cut does exist as in the case of $R_{a}$. The minimum $R_{t}$ was achieved at the following conditions: spindle speed $=500 \mathrm{rpm}$, depth of cut $=0.29 \mathrm{~mm}$, and table feed rate $=50 \mathrm{~mm} / \mathrm{min}$. It is noticed that only the feed rate value is common between minimum $R_{a}$ and minimum $R_{t}$. Moreover, multiobjective optimization was conducted with the target of minimizing $R_{a}$ and maximizing metal removal rate $(Q)$. The optimization resulted in spindle speed of $1250 \mathrm{rpm}$, depth of cut of $1.0 \mathrm{~mm}$, and table feed rate of $67 \mathrm{~mm} / \mathrm{min}$ with a composite desirability of 0.83 , to give $R_{a}$ and (Q) values of 0.15 and $2333 \mathrm{~mm}^{3} / \mathrm{min}$, respectively.

\section{Appendix}

See Tables 6 and 7.

\section{Nomenclature}

$a_{p}:$ Depth of cut, $\mathrm{mm}$

$a_{e}$ : Working engagement, $\mathrm{mm}$

$N$ : Spindle speed, rpm

$V_{c}$ : Cutting speed, $\mathrm{m} / \mathrm{min}$

$V_{f}$ : Table feed rate, $\mathrm{mm} / \mathrm{min}$

$Z_{n}$ : Total number of teeth in cutter

Q: Metal removal rate, $\mathrm{mm}^{3} / \mathrm{min}$.

\section{Competing Interests}

The authors declare that they have no competing interests.

\section{Acknowledgments}

This project was supported by King Saud University, Deanship of Scientific Research, College of Engineering Research Center. 
TABLE 7: Cutting conditions for group B.

\begin{tabular}{|c|c|c|c|c|c|c|}
\hline \multirow{2}{*}{$\begin{array}{l}\text { Test } \\
\text { number }\end{array}$} & \multirow{2}{*}{$\begin{array}{c}\text { Group } \\
\#\end{array}$} & \multirow{2}{*}{$\begin{array}{c}\text { Spindle speed } \\
(\mathrm{rpm})\end{array}$} & \multirow{2}{*}{$\begin{array}{l}\text { Depth of cut } \\
(\mathrm{mm})\end{array}$} & \multirow{2}{*}{$\begin{array}{l}\text { Table feed } \\
(\mathrm{mm} / \mathrm{min})\end{array}$} & \multicolumn{2}{|c|}{ Surface finish $(\mu \mathrm{m})$} \\
\hline & & & & & $R_{a}$ & $R_{t}$ \\
\hline $\mathrm{B} 1$ & \multirow{4}{*}{ B1 } & \multirow{4}{*}{500} & \multirow{4}{*}{0.25} & 50 & 0.044 & 0.298 \\
\hline B2 & & & & 75 & 0.122 & 1.042 \\
\hline B3 & & & & 100 & 0.153 & 1.200 \\
\hline B4 & & & & 125 & 0.204 & 1.417 \\
\hline B5 & \multirow{4}{*}{ B2 } & & \multirow{4}{*}{0.5} & 50 & 0.056 & 0.338 \\
\hline B6 & & & & 75 & 0.130 & 0.948 \\
\hline B7 & & & & 100 & 0.173 & 1.257 \\
\hline B8 & & & & 125 & 0.211 & 1.368 \\
\hline B9 & \multirow{4}{*}{ B3 } & \multirow{4}{*}{500} & \multirow{4}{*}{0.75} & 50 & 0.075 & 0.854 \\
\hline $\mathrm{B} 10$ & & & & 75 & 0.166 & 1.133 \\
\hline B11 & & & & 100 & 0.196 & 1.371 \\
\hline B12 & & & & 125 & 0.235 & 1.428 \\
\hline $\mathrm{B} 13$ & \multirow{4}{*}{ B4 } & \multirow{4}{*}{500} & \multirow{4}{*}{1.00} & 50 & 0.087 & 0.928 \\
\hline B14 & & & & 75 & 0.208 & 1.216 \\
\hline B15 & & & & 100 & 0.242 & 1.401 \\
\hline B16 & & & & 125 & 0.256 & 1.598 \\
\hline $\mathrm{B} 17$ & \multirow{4}{*}{ B5 } & \multirow{4}{*}{750} & \multirow{4}{*}{0.25} & 50 & 0.085 & 0.605 \\
\hline B18 & & & & 75 & 0.186 & 1.223 \\
\hline B19 & & & & 100 & 0.209 & 1.738 \\
\hline B20 & & & & 125 & 0.240 & 1.479 \\
\hline B21 & & & & 50 & 0.088 & 0.872 \\
\hline B22 & B6 & 750 & 0.5 & 75 & 0.106 & 1.067 \\
\hline B23 & DO & 150 & & 100 & 0.117 & 1.150 \\
\hline B24 & & & & 125 & 0.146 & 1.179 \\
\hline B25 & & & & 50 & 0.098 & 0.900 \\
\hline B26 & B7 & 750 & 0.75 & 75 & 0.121 & 1.102 \\
\hline B27 & & & & 100 & 0.138 & 1.318 \\
\hline B28 & & & & 125 & 0.169 & 1.549 \\
\hline B29 & & & & 50 & 0.110 & 1.002 \\
\hline B30 & B8 & 750 & 100 & 75 & 0.200 & 1.990 \\
\hline B31 & Do & 150 & 1.00 & 100 & 0.296 & 2.143 \\
\hline B32 & & & & 125 & 0.356 & 2.261 \\
\hline B33 & & & & 50 & 0.049 & 0.338 \\
\hline B34 & B9 & 1000 & 0.25 & 75 & 0.100 & 0.896 \\
\hline B35 & & & & 100 & 0.120 & 1.007 \\
\hline B36 & & & & 125 & 0.140 & 1.176 \\
\hline B37 & & & & 50 & 0.096 & 0.605 \\
\hline B38 & $\mathrm{B} 10$ & 1000 & 0.5 & 75 & 0.118 & 0.952 \\
\hline B39 & & & & 100 & 0.136 & 1.112 \\
\hline B40 & & & & 125 & 0.239 & 1.722 \\
\hline B41 & & & & 50 & 0.110 & 0.746 \\
\hline B42 & $\mathrm{B} 11$ & 1000 & 075 & 75 & 0.221 & 1.362 \\
\hline B43 & & & & 100 & 0.240 & 1.677 \\
\hline B44 & & & & 125 & 0.262 & 1.857 \\
\hline B45 & & & & 50 & 0.118 & 0.856 \\
\hline B46 & B12 & 1000 & 100 & 75 & 0.242 & 1.600 \\
\hline B47 & & & & 100 & 0.268 & 1.917 \\
\hline B48 & & & & 125 & 0.279 & 2.142 \\
\hline
\end{tabular}


TABLE 7: Continued.

\begin{tabular}{|c|c|c|c|c|c|c|}
\hline \multirow{2}{*}{$\begin{array}{l}\text { Test } \\
\text { number }\end{array}$} & \multirow{2}{*}{$\begin{array}{c}\text { Group } \\
\# \\
\end{array}$} & \multirow{2}{*}{$\begin{array}{l}\text { Spindle speed } \\
(\mathrm{rpm})\end{array}$} & \multirow{2}{*}{$\begin{array}{l}\text { Depth of cut } \\
(\mathrm{mm})\end{array}$} & \multirow{2}{*}{$\begin{array}{l}\text { Table feed } \\
(\mathrm{mm} / \mathrm{min})\end{array}$} & \multicolumn{2}{|c|}{ Surface finish $(\mu \mathrm{m})$} \\
\hline & & & & & $R_{a}$ & $R_{t}$ \\
\hline B49 & \multirow{4}{*}{ B13 } & \multirow{4}{*}{1250} & \multirow{4}{*}{0.25} & 50 & 0.060 & 0.861 \\
\hline B50 & & & & 75 & 0.110 & 1.084 \\
\hline B51 & & & & 100 & 0.145 & 1.113 \\
\hline B52 & & & & 125 & 0.165 & 1.437 \\
\hline B53 & \multirow{4}{*}{ B14 } & \multirow{4}{*}{1250} & \multirow{4}{*}{0.5} & 50 & 0.065 & 0.406 \\
\hline B54 & & & & 75 & 0.122 & 0.899 \\
\hline B55 & & & & 100 & 0.138 & 0.908 \\
\hline B56 & & & & 125 & 0.166 & 1.000 \\
\hline B57 & \multirow{4}{*}{ B15 } & \multirow{4}{*}{1250} & \multirow{4}{*}{0.75} & 50 & 0.068 & 0.323 \\
\hline B58 & & & & 75 & 0.129 & 1.235 \\
\hline B59 & & & & 100 & 0.175 & 1.346 \\
\hline B60 & & & & 125 & 0.201 & 2.189 \\
\hline B61 & \multirow{4}{*}{ B16 } & \multirow{4}{*}{1250} & \multirow{4}{*}{1.00} & 50 & 0.075 & 0.412 \\
\hline B62 & & & & 75 & 0.165 & 1.516 \\
\hline B63 & & & & 100 & 0.192 & 1.715 \\
\hline B64 & & & & 125 & 0.225 & 1.822 \\
\hline
\end{tabular}

\section{References}

[1] K. V. M. K. Raju, G. R. Janardhana, P. N. Kumar, and V. D. P. Rao, "Optimization of cutting conditions for surface roughness in CNC end milling," International Journal of Precision Engineering and Manufacturing, vol. 12, no. 3, pp. 383-391, 2011.

[2] D. Y. Pimenov, "Experimental research of face mill wear effect to flat surface roughness," Journal of Friction and Wear, vol. 35, no. 3, pp. 250-254, 2014.

[3] F. Pusavec, A. Deshpande, S. Yang et al., "Sustainable machining of high temperature Nickel alloy-Inconel 718: part 2-chip breakability and optimization," Journal of Cleaner Production, vol. 87, pp. 941-952, 2015.

[4] C. Felho and J. Kundrak, "CAD-based modelling of surface roughness in face milling," International Journal of Mechanical, Aerospace, Industrial and Mechatronics Engineering, vol. 8, no. 5, pp. 814-818, 2014.

[5] S. Rawangwong, J. Chatthong, R. Burapa, and W. Boonchouytan, "An investigation of optimum cutting conditions in face milling semi-solid AA 7075 using carbide tool," International Journal of Innovation, Management and Technology, vol. 3, no. 6, pp. 692-696, 2012.

[6] T. Kivak, "Optimization of surface roughness and flank wear using the Taguchi method in milling of Hadfield steel with PVD and CVD coated inserts," Measurement, vol. 50, no. 1, pp. 19-28, 2014.

[7] S. Rawangwong, J. Chatthong, J. Rodjananugoon, R. Burapa, and W. Boonchouytan, "An investigation of optimum cutting conditions in face milling nodular cast iron FCD 400 using carbide tool," International Journal of Materials, Mechanics and Manufacturing, vol. 1, no. 4, pp. 309-313, 2013.

[8] A. T. M. Abbas, "Comparative assessment of wiper and conventional carbide inserts on surface roughness in the turning of high strength steel," Journal of Materials Science Research, vol. 5, no. 1, pp. 32-45, 2015.

[9] Y. Zhang and K. Chou, "A parametric study of part distortions in fused deposition modelling using three-dimensional finite element analysis," Proceedings of the Institution of Mechanical
Engineers, Part B: Journal of Engineering Manufacture, vol. 222, no. 8, pp. 959-967, 2008.

[10] D. Fydrych and G. Rogalski, "Effect of shielded-electrode wet welding conditions on diffusion hydrogen content in deposited metal," Welding International, vol. 25, no. 3, pp. 166-171, 2011.

[11] T. Ding, S. Zhang, Y. Wang, and X. Zhu, "Empirical models and optimal cutting parameters for cutting forces and surface roughness in hard milling of AISI H13 steel," International Journal of Advanced Manufacturing Technology, vol. 51, no. 1, pp. 45-55, 2010.

[12] D. C. Montgomery, Design and Analysis of Experiments, John Wiley \& Sons, 2013. 

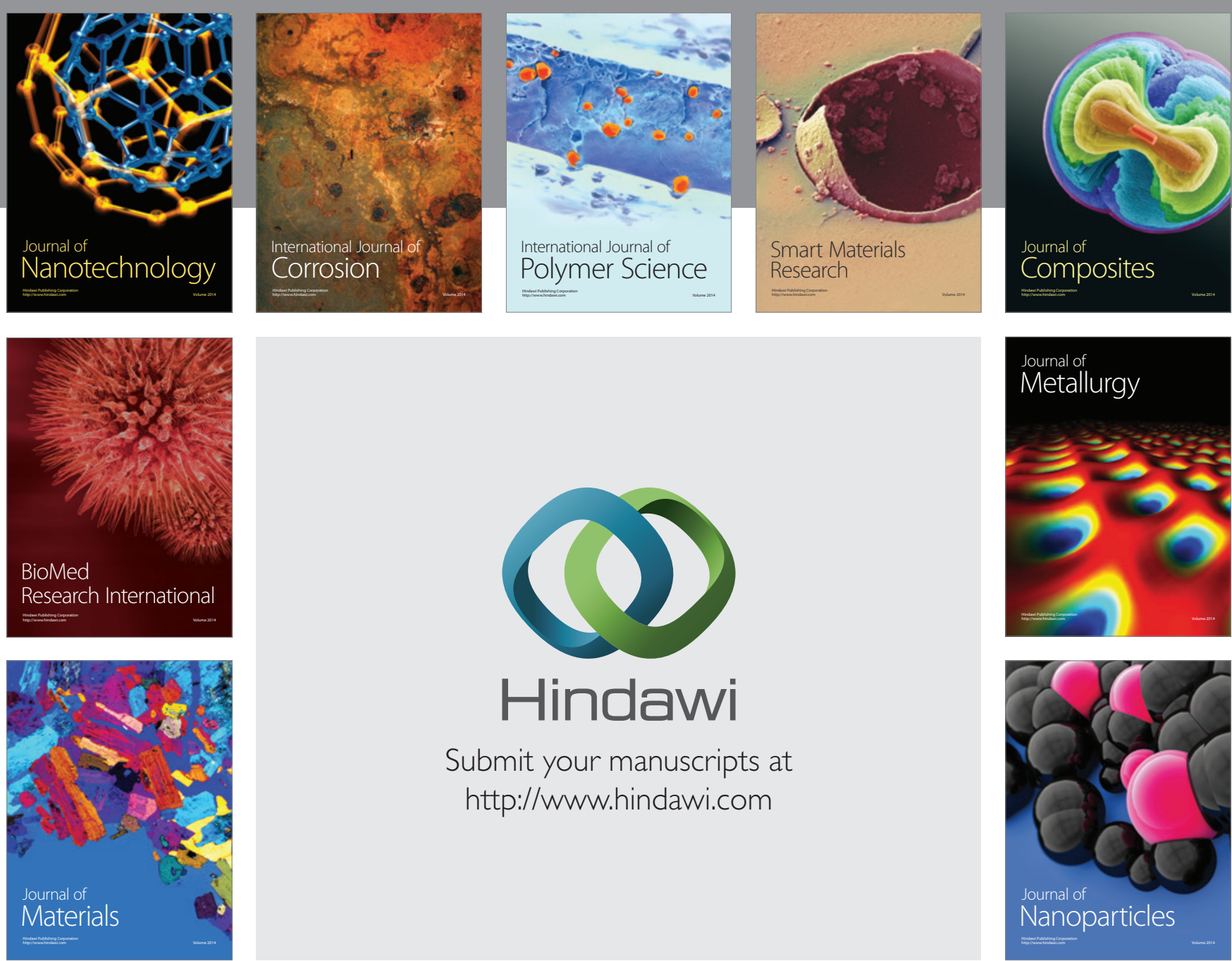

\section{Hindawi}

Submit your manuscripts at

http://www.hindawi.com

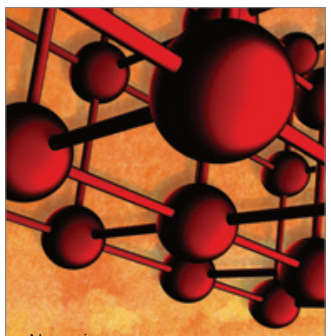

Materials Science and Engineering
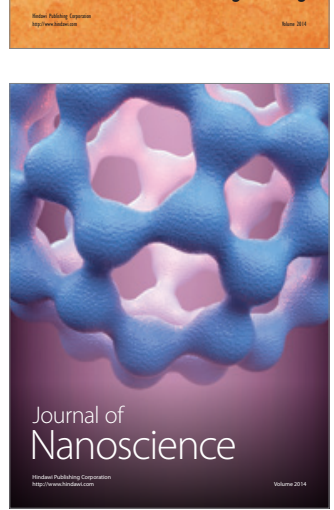
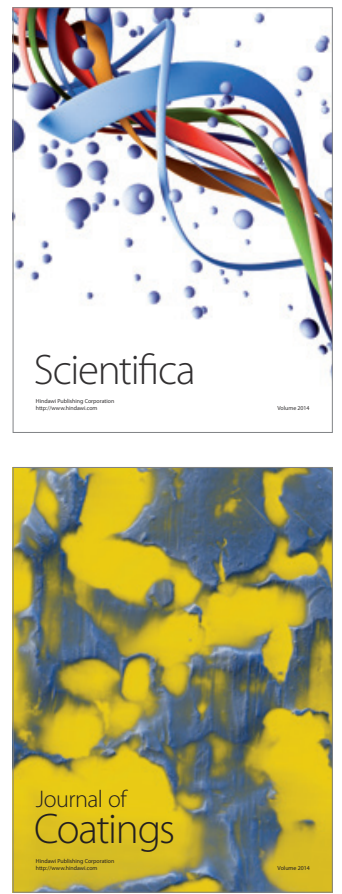
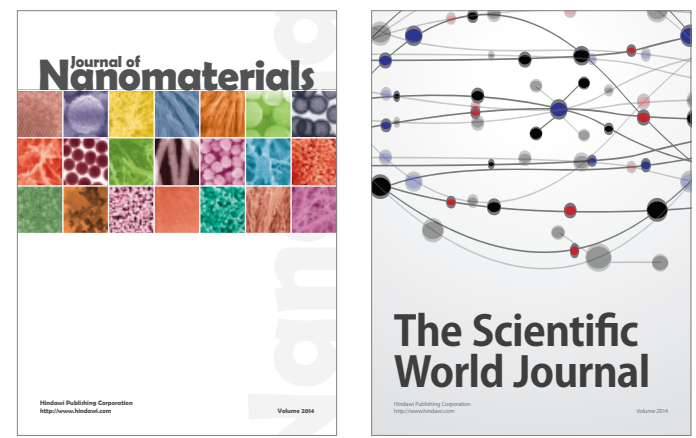

The Scientific World Journal
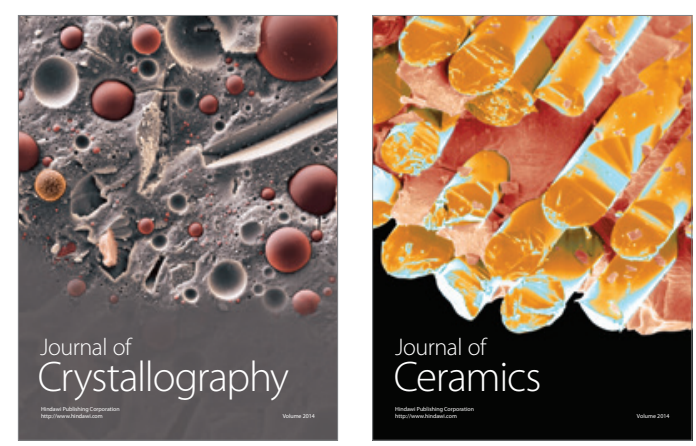
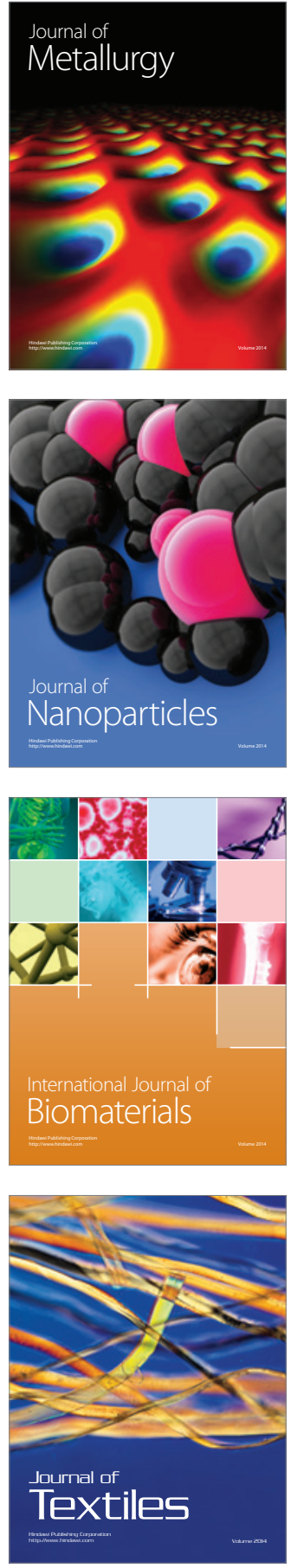